\title{
MEASURED SECTION FOR THE POSSIBLE STRATOTYPE OF THE MIRI FORMATION, AT MIRI HILL, NORTH SARAWAK, MALAYSIA
}

\author{
Muhd Nur Ismail Abdul Rahman*, Sanudin Hj. Tahir \\ Faculty of Science and Natural Resources, Universiti Malaysia Sabah. \\ *Corresponding Author Email: ismailar,rakiti89@gmail.com
}

This is an open access article distributed under the Creative Commons Attribution License, which permits unrestricted use, distribution, and reproduction in any medium, provided the original work is properly cited.

\section{ARTICLE DETAILS}

Article History:

Received 26 June 2018

Accepted 2 July 2018

Available online 1 August 2018

\section{ABSTRACT}

The Miri Formation is continuously studied by many researchers in various aspects and disciplines in geology due to the important petroleum reservoir since the period of production in 1920-1941. The aim of this study is to analyse a basic principle of postulated type locality found in Miri area. A complete sequence of the Miri Formation (measured section) is exposed at Oil Well road which is related to the Miri Formation. The distribution of outcrops is widely distributed at a few localities in Miri region such as Tanjong Lobang, Airport road, Hospital road and Oil Well road. The rock formation is preserves a complete sequence of sedimentary facies established for the Miri Formation. The section comprises the following facies; facies 1: planar cross stratified (PcS), facies 2: swaley cross stratified (ScS), facies 3: swaley-Hummocky cross stratified (SHcS), facies 4: Hummocky cross stratified (HcS) and facies 5: parallel laminae facies. Those facies are interpreted to have been deposited from offshore, lower shoreface to foreshore setting at a shoreline system. This measured section found stands by itself without referring to another rock unit either lateral or vertical distribution except the information reported by former researchers that they used subsurface data to evaluate other formation (lithostratigraphic unit) related to it.

\section{KEYWORDS}

Miri Formation, facies, stratotype, type section, foreshore.

\section{INTRODUCTION}

The research area is located at Miri region. The measured section is located at Tanjong Lobang, Airport road, Hospital road and Oil Well road. The area is wholly covered by the Miri Formation with an elevation peak is moderated and about 100 meters above sea level. The study area is enclosed by longitudes between $113^{\circ} 20^{\prime} \mathrm{E}$ to $114^{\circ} 20^{\prime} \mathrm{E}$ and between the latitudes of $4{ }^{\circ} 16^{\prime} \mathrm{N}$ to $4^{\circ} 24^{\prime} \mathrm{N}$. A body of a complete sequence of the the Miri Formation is out cropped at Oil Well road (figure 1) near to Miri town.

The Miri Formation was named after Miri anticline, at Miri Oilfield, north Sarawak [1]. In this area, they stated that the Miri Formation is divided into Upper Miri and Lower Miri units according to lithological changes displayed between those units. Both units can be differentiated by its sand-mud ratio where Upper Miri is more arenaceous as compared to Lower Miri. The Miri Formtion also exposed in Seria Field, Lambir Hill, Belait anticline and Jerudong, Brunei Darussalam. From our observation, most of these localities have similar characteristics to the Miri Formation include micro-paleontology, similar lithology and stratigraphic relationship [1].

According to a study, the Miri Formation achieve its maximum thickness over 1828.8 metre at Seria Field, 1310.64 metre at Miri Oil Field, Lambir Hills about 1295.4 metre and at Belait Anticline about 1463.04 to 1645.92 metre [1]. Those thicknesses are comparable to reservoir seismic database measurement with whole estimation of type section is incomplete because the Lower and Upper Miri is not juxtaposed in appearance. This study is to propose a complete lithostratigraphic sequence namely the type section of the Miri Formation.

\section{GEOLOGICAL BACKGROUND}

The Miri Formation is predominantly arenaceous with a lithology similar to the Belait Formation. In Miri Field, formation is divided into Lower and Upper Miri formation [1]. The Lower Miri consists of a succession of interbedded sandstones and mudstone which are separated in major; well define bodies of similar size, the mudstone slightly prevailing. The Upper
Miri is more arenaceous; the alternation of sandstone and shales take place more rapidly and is less regular; the sandstone bodies merge more gradually into argillaceous sandstone and sandy or silty shale.

According to a study, the rock unit consists of alternation of thick sandstone and siltstone intercalated with thin shale [2]. Meanwhile, other study state that the Miri Formation is predominantly arenaceous, with clay and shale [3]. They shares similar view to Liechti, toward the Miri Formation which this formation was divided into two lithologic units; the Upper and the Lower unit. The maximum thickness is over $6000 \mathrm{feet}$, in the Seria Field and range from 304.8 to 1219.21 in Miri Field [1].

Facies analysis of the Miri Formation have been described based on shallow marine sedimentary structures [3-5]. The recorded sedimentary facies are; through cross bedding, herringbone cross bedding, hummockyswalley cross bedding, flaser-wavy bedding, lenticular bedding, planar cross bedding and parallel laminated sandstone. No type section has been assigned by the previous authors other than type locality from the geophysical logging [1].

Basically in Miri region it is harder to observe any relationship between other formations by using vertical log analysis. However, in relation to previous report in Seria and Miri subsurface, the basal boundary with the underlying Setap Shale Formation is a gradual transition from an arenaceous into a predominantly argillaceous succession [1]. In the Bakam-Lambir area, the basal boundary of the Miri Formation with the Lambir Formation is fairly well defined, the top sandstone of the Lambir Formation lied in contrast with argillaceous Miri Formation. Stratigraphically, the Miri Formation is surrounded by several other lithostaratigraphic units i.e. the Tukau Formation, The Belait Formation, The Lambir Formation and the Seria Formation. These sediments were deposited from Early Miocene to Late Miocene [2]. In this study, the Miri Formation is considered to be deposited between Middle to Late Miocene (Figure 2). 


\section{METHODOLOGY}

Throughout the research, one of the most important methods used is stratigraphic analysis by using critical startigraphic concept and sedimentology parameters as a whole. Most of the methods used in this research including field data collection such as site visit observation, measuring outcrop sections and vertical log analysis. Basically, the stratigraphic procedures in this observation were carried out according to International Stratigraphic Guide [6]. The main focus of this study is to propose a type locality exposed in the Miri Formation.

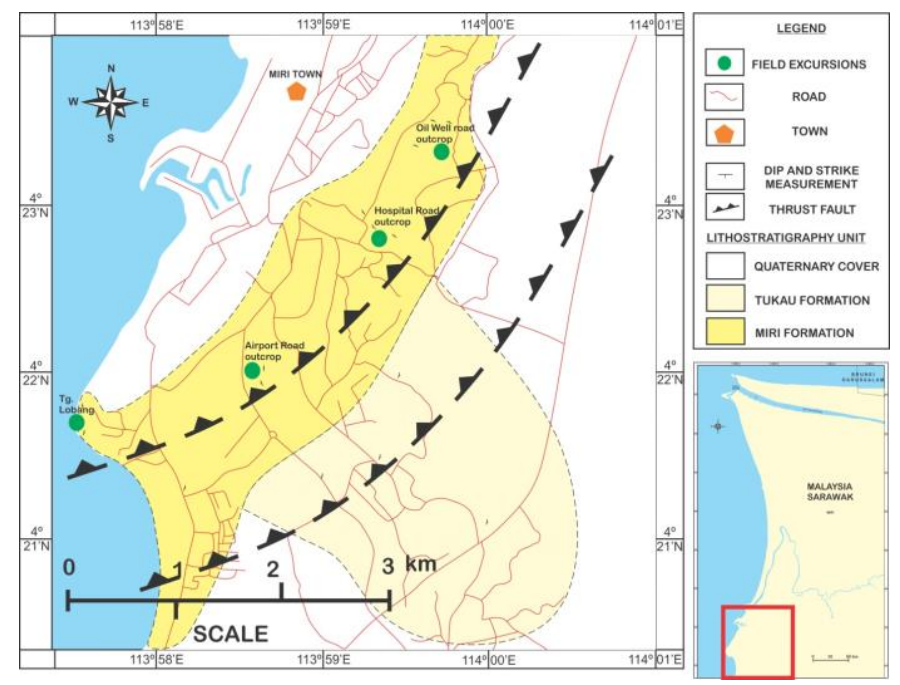

Figure 1: Map showing distribution of the Miri Formation and the location of study area [7]

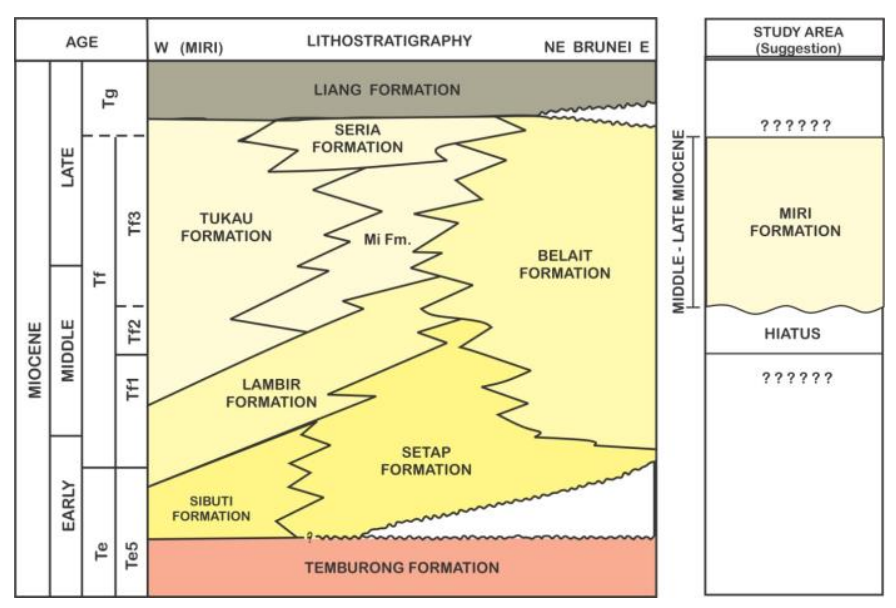

\section{RESULT AND DISCUSSION}

\subsection{Miri Formation}

\subsubsection{General Aspect}

The Miri Formation basically consists of interbedded sandstonemudstone. However, the Miri Formation is named for a series of interbedded sandstone and shale but with a distinctive calcareous admixture (limestone, calcareous shale) than the Belait Formation which is completely absent [1]. Mostly the area around Miri region is consists of the Miri Formation [7]. Wide variety of rock units that exposed in the Miri region mostly are shallow marine origin [7]. At Oil Well outcrop, the upward sequence achieves 47 meters high vertically and 450 meters laterally (Figure 3). The sequence shows abundance of cross stratified structures within stacked sandstone. Thin to medium bedded mudstone is conspicuous variation in thickness where it occurs as interlayering with sandstone bed. The outcrop shows the sandstone bed is coarsening upward sequence. This is related to gradual change of grain size towards upper sequence of bed starting from offshore facies association to foreshore facies association and it is clearly shown on individual bed that the grain size is fining to coarsening upward sequence.

\subsubsection{Locality of Measured Section}

Complete sequence of the Miri Formation is cropped out at Oil Well Road, near Hospital Road. This area is located at longitude $115^{\circ} 59.810^{\prime} \mathrm{E}$ and latitude $04^{\circ} 23.530^{\prime} \mathrm{E}$ and is about $5 \mathrm{KM}$ from Miri Town. The outcrop is easy to access and it is exposed behind residential area and surrounded by higher topoghraphy of the Canada Hills. This area is the best exposure (according to complete facies exposed). The complete sequence of the Miri Formation is recorded as full established facies association ranging from offshore to foreshore environments (refer facies analysis and facies association) (Figure 3 (b) and figure 4). Other location exposed of this equivalent rock unit is at Jalan Padang Kerbau and Airport Road outcrop. However, both outcrops present incomplete stratigraphic section (type locality).

\subsubsection{Description of stratotype (type locality)}

Lateral distribution of the measured section at the study area is approximately covered 450 metre. The exposure is moderately dipping towards northeast-southwest $\left(35^{\circ}\right.$ to $\left.45^{\circ}\right)$ and lies as an intersection with growth fault. The section is generally exhibit coarsening upward sandstone sequence with minor alternate packages of heterolithic unit that largely reveals the geometry of tidally shoreface dominated facies association of shoreline environment. This type section proposed in this study is based on facies analysis of the Miri Formation.

Figure 2: Lithostartigraphic chart is related to the position of the Miri Formation [8]



Figure 3: (a) Complete sequence of outcrop is displayed an exposure of measured section of the Miri Formation. Photo from left hand side is indicated a complete facies established in an outcrop of the Miri Formation. (b) Vertical litholog analysis of the Miri Formation showing full representative of facies of the Miri Formation. 


\subsection{Facies Analysis}

\subsubsection{Facies 1: Planar cross stratified (PcS)}

\subsubsection{Description}

Facies 1 consists of thick planar cross bedded sandstone and thin mudstone bed (Photo 1). The individual bed is exposed as buff thick stacked sandstone ranging between $1 \mathrm{~m}$ to $3 \mathrm{~m}$ thick. Based on the vertical litholog constructed from the outcrop at Oil Well road, stacked sandstone bed with planar cross stratified is about $20 \mathrm{~cm}$ thick (Figure 4). Some part of sandstone beds are closed to amalgamated pattern which is located in an upper part position. A mud unit also exposed as interbedded with sandstone bed with $10 \mathrm{~cm}$ thick. The planar sandstone bed is good sorting and ranges from medium to coarse grain size.

\subsubsection{Interpretation}

Occurrence of thick, amalgamated and stacked planar cross bed is related to high regime of wave in an upper part of a beach profile. A series of planar cross set basically is a result from straight migration of ripple during wave activity. Evidence of good sorting from medium to coarse grain size is due to winnowing process and then could be prolonged process of storm wave.

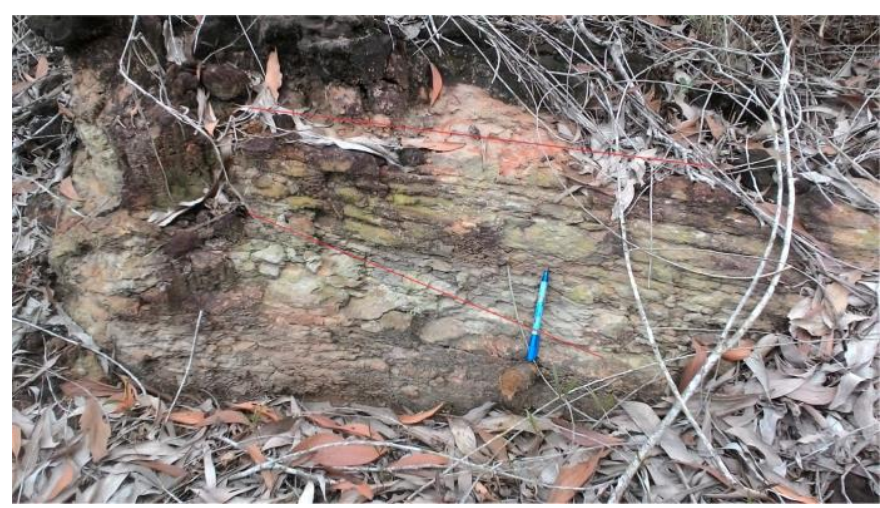

Photo 1: Planar cross stratified exposed at Oil Well outcrop. A pen as scale.

\subsubsection{Facies 2: swaley cross stratified (ScS)}

\subsubsection{Description}

Facies 2 comprises of moderately to well sorted, fine to medium grain size and range up to 8 meters thick (approximately average of one outcrop). This facies is distributed intermittently around Miri such as at Tanjung Lobang outcrop, Hospital road outcrop and Jalan Oil Well outcrop. Referring to the outcrop at Jalan Oil Well, the swaley bedding ranges from $50 \mathrm{~cm}$ to 1 meter thick (Figure 4). At Tanjung Lobang outcrop however, the swaley cross bedding displayed a small scale of cross bedding within the range of $5 \mathrm{~cm}$ to $10 \mathrm{~cm}$ (Photo 2 (a), (b) and (d)). In this area the grain size is graded upward into medium to coarse grained sandstone.

\subsubsection{Interpretation}

In such a setting storms would create shallow scours (elliptical to circular in plan view) filled by flattening upward laminae conforming to the shape of the swale that contribute to swaley cross stratification of the rock sequence in the upper shoreface area [9]. Coarsening upward of grain size from fine to medium size showed that increase in flow velocity through time of deposition and is most energetic part of the system $[10,11]$.



Photo 2: (a) Swaley Cross bed outcrop. (b) Enlargement scale of swaley cross bed. (c) Thalassinoides sp. exposed on sandstone bed. (d) The swaley cross lamination with a few sets of angle.

\subsubsection{Facies 3: Swaley-Hummocky cross stratified (SHcS)}

\subsubsection{Description}

Interbedded sandstone with mudstone, fine to medium grain size, scoured-based and coal lenses are related to facies 3 . This facies exposed mostly at Tanjung Lobang outcrop, Hospital road outcrop and Jalan Oil well outcrop (Figure 4 and 5). The best exposure of this facies is at Tanjung Lobang outcrops and Jalan Oil Well outcrops. At Tanjung Lobang outcrop this facies is 5 meters thick where the swalley and hummocky (SHcS) lies alternately in one sequence (Photo 3 ). It shows that the hummocky cross stratified lied at lower bed position and then continuously repeated by medium scale of swalley cross stratified in upper bed position. Whereas at Jalan Oil Well outcrop this sedimentary structure lies in sandstone bed but it is interbedded with mudstone.

\subsubsection{Interpretation}

Variety of grain sizes, fine to medium interval are resulted from slowing down the energy of wave. The swaley and hummocky occur is due to density current suspension after deposition by continuous storm wave is subjected to the bottom (sediment) and finally create a mould at the middle shoreface area. The mould formed is based on how large a wave action to the sediment during the storm event.

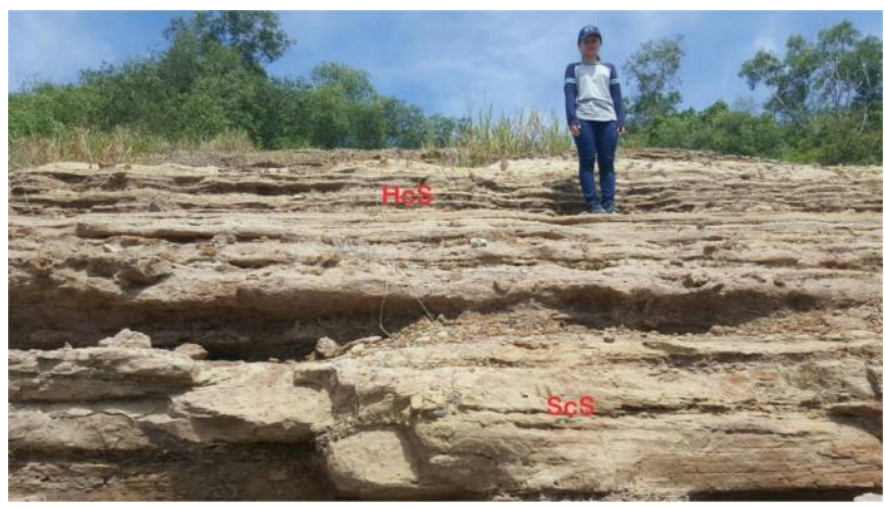

Photo 3: The swaley-hummocky cross stratified is overlying another. It is showing that the swaley cross stratified is overlain by hummocky cross stratified.

\subsubsection{Facies 4: Hummocky cross stratified (HcS).}

\subsubsection{Description}

Facies 4 is recognized as sandstone interbedded with mudstone, bad to moderately sorted grain size and various pattern of sandstone bedding (scour resembling swales bed, contorted bed, disconnected bed, nonhomogeneous bed). One of the best exposure outcrop displayed of this facies is at Hospital road outcrop. The upward sequence achieves 30 meters high vertically and 40 meters horizontally (Photo 4 (a)). The bedding geometry showed within the range from $5 \mathrm{~cm}$ and up to 1 meter thick. The mudstone is generally abundant in an upper part of the outcrops which is achieved 60 meter thick. 


\subsubsection{Interpretation}

Basically disconnected bed and non-homogenous exposed in a few section in an outcrop is related to natural erosion during storm at the lower most part of the shoreface above a storm wave base. According to a study, this hummocky cross bed is result from low net deposition due to sediment by pass but in other study stated that it may accumulate after repeating storm reworking in high energy setting $[12,13]$.

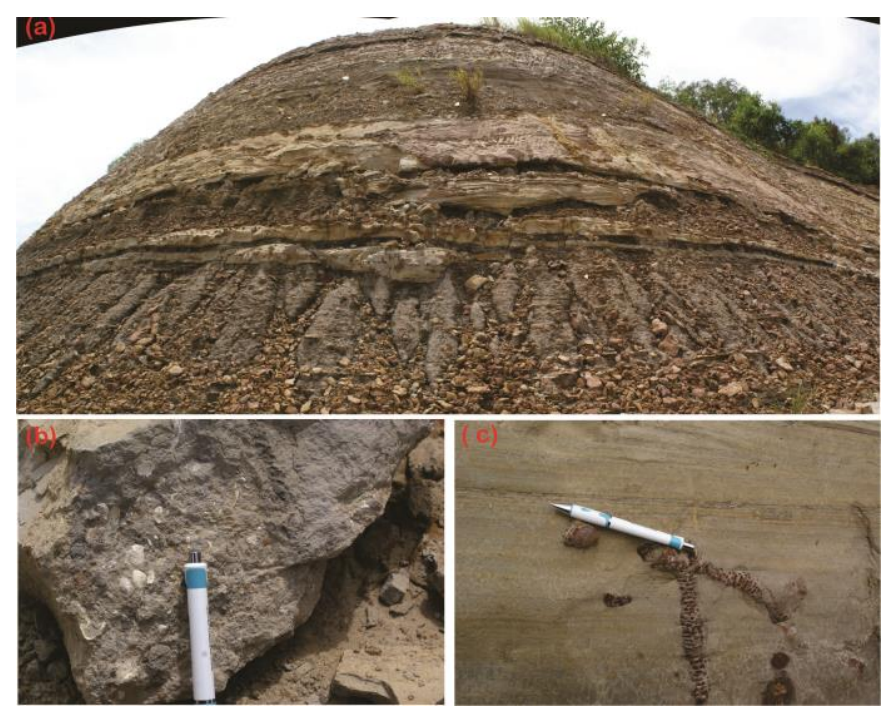

Photo 4: (a) Large outcrop of Hummocky cross bed, Hospital road. (b) Some macrofossils found in a sandstone bed. (c) Some ophiomorpha sp. lies on sandstone bed.

\subsubsection{Facies 5: Parallel Laminated siltstone and mudstone bed (Psm)}

\subsubsection{Description}

This facies is consists of parallel laminated bedding of siltstone and mudstone (Photo 5 (a)). The siltstone bed mostly undisturbed and structureless. The structureless siltstone basically has an obscure sedimentary structure with $\mathrm{dm}$ to $\mathrm{cm}$ thick beds of silt to fine grained size. This is due to weathering process or poor preservation during deposition. Exposure of parallel mudstone in this facies is limited. It is displayed by alternate heterolithic mud and then interbedded with parallel thin sandstone bed (Photo 5 (b))

\subsubsection{Interpretation}

We interpret that the parallel lamination occurs is due to slow motion of current or non-effected by wave or storm dominated condition. Interbedded siltstone and mudstone indicate reversal current of wave during slow energy below storm wave base. Thus sedimentary particle is in the form of clay, silt and fine sand. Structureless siltstone is related to less or slow current activity in offshore environment.

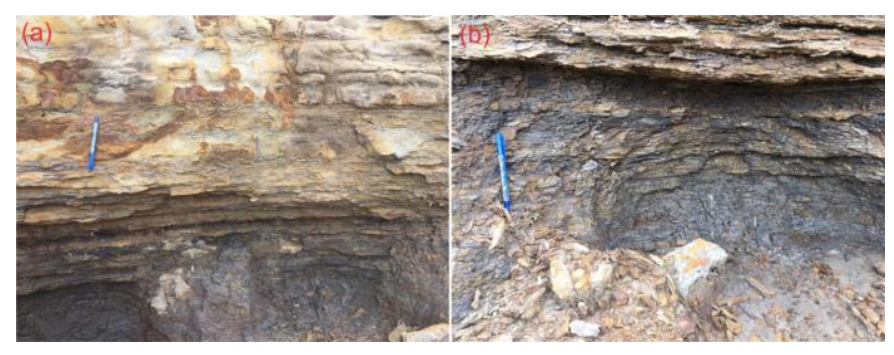

Photo 5: (a) Parallel laminated siltstone and mudstone facies exposed at Oil Well outcrop. (b) heterolithic laminated mud exposed at lower bed.

\subsection{Facies Association}

\subsubsection{Facies Association 1 (FA 1): Foreshore}

\subsubsection{Description}

Facies association 1 consists of thick planar cross bedded sandstone. This facies is found as extensively succession that shows medium to coarse grain size in upward sequence of bed. The grain size is generally well sorted. Sedimentary structures in this facies include high angle herringbone structure (Photo 6 (c)) and intermittently interbedded with thin bedded heterolithic unit (flaser) that showing an upward sequence (Photo 6 (a)). Coal lenses are common in this co-set. Burrows and other bioturbations are not too common in this outcrop but some Ophiomorpha $s p$ is present in some part of the sandstone layers (Photo $6(\mathrm{~b})$ ).

\subsubsection{Interpretation}

The planar cross stratified (PcS) exists in this facies showed a high angle co-set of cross bedding, caused by high regime of storm during phase of deposition. Evidence of good sorting from medium to coarse grain size is due to winnowing process and then could be prolonged process of storm wave. We consider the dominant structures occur in this facies like planar cross stratified and wedging structure is due to wave generated system inner foreshore part of the sedimentary environment. However occurrence of flaser-tidally structure in this sandstone is not exactly in a same system of wave dominated because of it limited appearance and mere a fragment of mud that has been deposited during microtidal event. According to a study, mixture of sand and mud in the heterolithic layer will happen due to variation of current or wave activity and sediment supply due to changing of current strength and wave power [10]. Less bioturbation in this facies is because of slowing growth of organism in high wave dominated area.
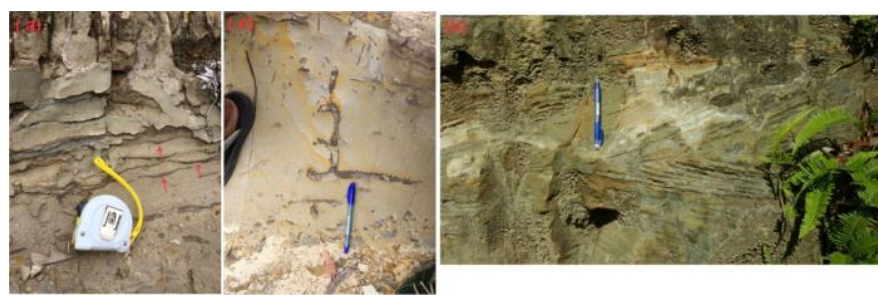

Photo 6: a) Flaser bedded structure. (b) bi-directional herringbone cross bed with high angle of co-set bedding. (c) Ophiomorpha sp. on a sanstone bed.

\subsubsection{Facies Association 2 (FA 2): Upper Shoreface}

\subsubsection{Description}

This facies association comprises of thick cross bedded sandstone which is an individual bedding showed a co-set of high to low angle of cross bedding including through cross bed and swaley cross stratified (ScS) (Photo 2 (a) and (b)). Actually both structures are easy to identify at field due to scale of angle can be distinguishable between them. Bedding plane is scoured, undulating surface and irregular pattern. In a vertical section at Oil well outcrop, this FA 3 is a gradually transition from fine, medium to coarse grain FA 2 sandstone. Boundary between FA 2 and FA 1 is obscured within Oil Well outcrop but can be identified through pattern of cross beded structure. Moderately medium to large burrows of trace fossils like Ophiomorpha $s p$ and Thalassinoides $s p$ are common on sandstone bed (Photo 2 (c)).

\subsubsection{Interpretation}

Well sorted, variety of grain size from fine to medium grained sandstone with the existence of swaley cross bedded is a good indicator of upper shoreface environment. Existence of high angle through cross bed indicate high energy of storm occur during deposition. This is due to wave progressively move landward and tend to be asymmetric $[14,15]$. Sort of bedding plane like scour, undulating surface and irregular pattern is mostly because colliding of storm with sediment bottom during deposition. Moderately abundant of trace fossils with simple burrow systems characterizes upper shoreface environment sandstones [16]. Another indicator is existence of Large to medium trace fossils like Ophiomorpha $s p$ and Thalassinoides $s p$ which mean bigger animals for favourable environment.

\subsubsection{Facies Association 3 (FA 3): Middle Shoreface}

\subsubsection{Description}

This facies association consists of hummocky (HcS) and swaley cross stratified (ScS) sandstone bed. Both structures are overlain each others in one section. Some sections in Oil Well outcrops showed that the swaley cross bed is thicker than hummocky cross bed which is ranged from $50 \mathrm{~cm}$ to 1 metre. Variety of grain size orientation like fine to medium size with rare of coarse grain is dominantly displayed in bed. Mostly beds are showing coarsening upward sequence. Moderate to highly bioturbation of Ophiomorpha and Thalassinoides can be observed in an individual bed. 


\subsubsection{Interpretation}

Existence of hummocky cross stratified (HcS) is overlain by swalley cross stratified (ScS) indicates that the environment is fair-weather wave influenced while the settlement of sand and mud become uncertain. This is supported by others researcher, where swaley is formed between fair weather and storm wave base above hummocky cross stratification but below foreshore sub environment [17]. The variety of grained sizes of sandstone with the existence of swaley cross-stratification which can be seen on Figure 3 is a good indicator for middle shoreface until upper shoreface. The overlying swaley cross-strata are characteristic of a stormdominated, middle to upper shoreface environment. Moderate to highly bioturbation with abundant of Ophiomorpha and Thalassinoides with complex burrow systems characterize lower shoreface sandstones [6].

\subsubsection{Facies Association 4 (FA 4): Lower Shoreface}

\subsubsection{Description}

This facies association is composed of interbeded hummocky cross bed sandstone (HCS) with mudstone bed. This FA 3 is characterized with fine to medium grain size and some of them are well sorted. Large hummocky cross bed can be seen at Hospital road outcrop which is 1 meter thick without displaying any cross uset. Bedding plane is mostly showed that non-irregular bottom line with non-homogenous bedding sequence. Relationship between another facies like offshore unit can be seen at Oil Well road which is located below the lower part of the outcrops. Bioturbation is quite intense in every single bed of sandstone, mostly various kind of ophiomorpha sp (Photo 4 (c)). Some macro fossils like shells, mollusc and bivalve also observed in certain part of sandstone and mudstone but partly dissolved (Photo 4 (b)).

\subsubsection{Interpretation}

The interbedded sandstone with mudstone indicates lateral variation due to decrease of wave energy in a lower shoreface environment. According to another study, the hummocky bed is formed due to combination of scour and deposition operation within brief span of time [18]. Hummocky cross bed also is a result from storm wave and occurs in the transition zone of fair weather wave base and storm wave base. The boundary between the sandstone dominated and the mudstone dominated portions of the succession is sharp and scoured, and is interpreted as the boundary between major subaqueous sandstone set above storm wave-base. Moderate to intense bioturbation with abundant of Ophiomorpha and Thalassinoides with complex burrow systems characterize lower shoreface sandstones [16]. Some macro fossils like shells, mollusc and bivalve within sandstone and mudstone indicate a transition from freshwater to brackish water conditions. This statement is supported by some researchers where they found the freshwater fossils and brackish water fossils within the Miri Formation [7].

\subsubsection{Facies Association 5 (FA 5): Offshore}

\subsubsection{Description}

Facies association 5 comprises of facies Psm which is predominantly laminated mud and thin bedded siltstone. Laminated mud is ranged from $\mathrm{mm}$ - to $\mathrm{cm}$ thick and consists of minor heterolithic unit. Weakly to moderately burrowed laminated mud is grey, structureless with minor lenticular pattern with containing parallel siltstone bed. Fine siltstone layer, consists of horizontal parallel lamination and well-preserved ripples. Minor to micro hummocky range from $5 \mathrm{~cm}$ to $8 \mathrm{~cm}$ found in some section within siltstone bed. A boundary between FA 5 and FA 4 is marked by changes in sedimentary structure (i.e. facies HcS with facies Psm) and erosional at the upper siltstone bed. The facies association display weak to moderate burrow system and low intensity of bioturbation. Bioturbation recorded in this facies association is moderate in siltstone and laminated mud. In siltstone bed the exposure of ophiomorpha sp. is common. However in laminated mud is rare.

\subsubsection{Interpretation}

Facies association 5 is indicated as decreasing of depositional energy and depositional rate according to fine siltstone and predominantly mud record. Slow movement of sediment flow align the particle in laminar pattern, therefore produce lamination bed. The small scale of hummocky lenses and parallel lamination represent a continuous reworking by current [19]. Heterolithic laminated mud occurrences in an offshore environment confirm the process of tidally influence condition during fair weather period. Storm wave base usually happen between lower shoreface and offshore which it is marked by the distinguishable of sedimentary structure and erosional bed. Weaker burrow system, laminated mud graded into fine siltstone in the heterolithic dominated intervals, showed that laminated mud did not deposited in slow deposition event but accumulated in typically increase of energy conditions in the turbulence, tidal energy and occasionally wave power. Related to that consideration this facies association is deposited in an upper part of offshore setting [20].

\section{Oil Well Road}

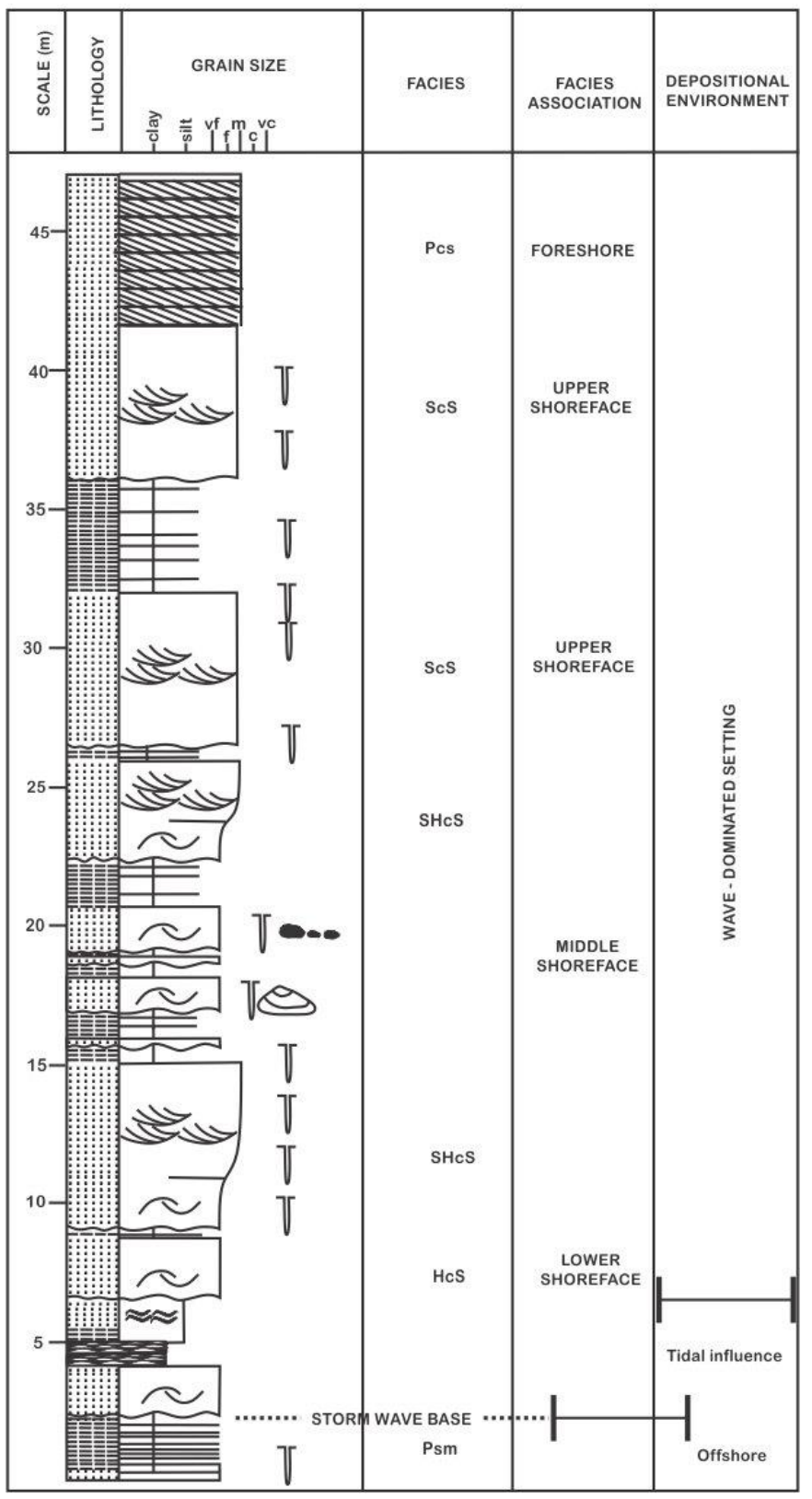

Figure 4: Facies 1, 2, 3 and 4 was exposed as a complete sequence of facies located at Oil Well outcrop. 


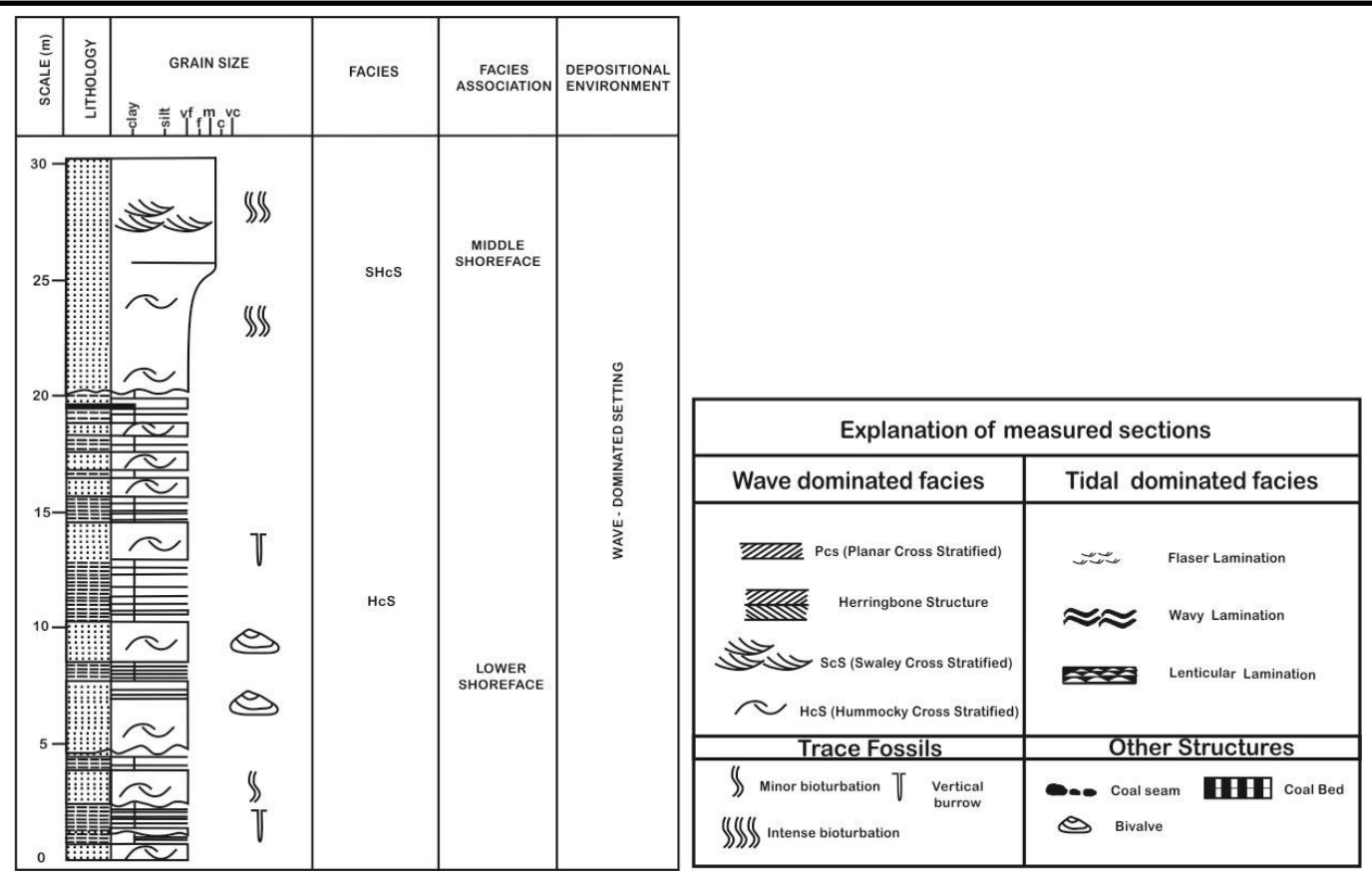

Figure 5: Vertical litholog analysis showing facies 3 and 4 at Oil Well outcrop

\section{ENVIRONMENTAL INTERPRETATION AND MODEL OF WAVE DOMINATED SETTING}

After examining all the structures and thickness of the rock units of the Miri formation, the depositional history of this formation then was evaluated. All of this information suggested that the formation has been deposited at a shallow marine environment, specifically at the shoreface depositional environment with the influence of wave and storm events.

According to a study, some structures attributed by most workers to storms are hummocky cross-stratification (HCS) [11]. Abundance of HCS is also a good indicator that the sediments have been deposited at the lower shoreface during the event of storms. Basically HCS are indicative of deposition in the lower part of a wave or generally preserved in areas of weak tidal activity that lie below fair-weather wave base and also indicative of deposition in the lower part of a wave or storm dominated shoreface [21].

The variety of grained sizes of sandstone with the existence of SCS which can be seen on photo 3 and 4 is a good indicator for middle shoreface until upper shoreface. In such a setting storms would create shallow scours (elliptical to circular in plan view) filled by flattening upward laminae conforming to the shape of the swale that contribute to SCS of the rock sequence in the area [9]. While the thick mudstone interbedded with the sandstone suggested a fair weather periods which contributes to the formation of sand pit somewhere in the middle of the lower shoreface and the middle shoreface. In many examples from the geological record, swaley cross-stratification sandbodies occur stratigraphically above hummocky cross-stratification sandstones and interbedded mudstones [21].

The abundance of amalgamated SCS and the existence of Planar cross stratification (PCS) in the sandstone give the best indicator of the upper shoreface to foreshore deposits. High regime of current subjected to sediment caused high angle of PCS. While on the upper part of this area is abundance with the medium to coarse grained sandstone, showing the characteristics of the upper shoreface [22]. The sediment typically coarsened toward the upper part of the shoreface, the most energetic part of the system [11].

This section of the outcrops were deposited at the shallow marine environment under the fluctuations of high and low flow wave dominated regimes which can be divided into foreshore (FA 2), upper shoreface (FA 3), middle shoreface (FA 4) and lower shoreface (FA 5) (Figure 6).

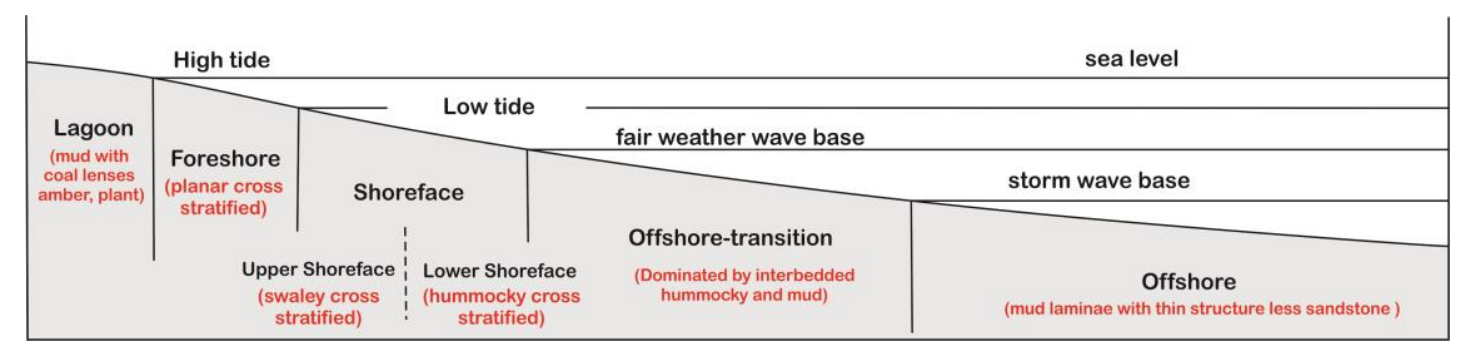

Figure 6: Suggestion an idealized schematic of the simplified beach and shoreface environment model of the Miri Formation.

\section{CONCLUSION}

This research was conducted by using vertical litholog measurement as a main method to analyse the whole sequences. The four locality sections given above of the clastic shoreline deposits varies according to the setting of the sediment, the shoreface morphology, the wave climate and the occurrence of storms and floods. On the basis of the dominant sediment distribution, the rock units have been identified four depositional sequences, namely; the offshore, lower shoreface, the middle shoreface, the upper shoreface and the foreshore. The measured section proposed for the Miri Formation at Oil Well road basically confirmed the previous proposal of the type locality by former researcher by using electrical marker from subsurface data to evaluate a complete sequence of the Miri Formation. However they only can show a type locality at that area instead of type section.

\section{REFERENCE}

[1] Liechti, P., Roe, F.N., Haile, N.S., Kirk, H.J.C. 1960. The geology of Sarawak, Brunei and the Western part of North Borneo. British Borneo Geological Survey, Bull 3.

[2] Banda, R.M., Honza, E. 1997. Miocene stratigraphy of northwest Borneo Basin. Geol. Soc Bull, (40), 1-11. 
[3] Hutchison, C.S. 2005. Geology of Northwest Borneo, Sarawak, Brunei and Sabah. Elsevier.

[4] Tan, D.N.K., Abd Rahman, A.H.B., Anuar, A., Bait, B., Tho, C.K. 1999. West Baram Delta. In: The Petroleum Geology and Resources of Malaysia. Petroleum Nasional Berhad (PETRONAS), Kaula Lumpur, Malaysia, pp. 293-341.

[5] Jia, T.Y., Rahman, A.H.A. 2009. Comparative analysis of facies and reservoir characteristics of Miri Formation (Miri) and Nyalau Formation (Bintulu), Sarawak. Bulletin of the Geological Society of Malaysia, 51, 6375 .

[6] Murphy, M.A., Salvador, A. 1999. International subcommission on stratigraphic classification of IUGS International commission on stratigraphy. International stratigraphic guide, 22, 4.

[7] Wannier, M., Lesslar, P., Lee, C., Raven, H., Sorkhabi, R., Ibrahim, A. 2011. Geological Excursions Around Miri, Sarawak. Eco. Media Software, $279 \mathrm{p}$.

[8] Sandal, S.T. 1996. The geology and hydrocarbon resources of Negara Brunei Darussalam. Brunei Museum Spec. Pub, Brunei Darussalam.

[9] Leckie, D.A., Walker, R.G. 1982. Storm- and tide-dominated shorelines in the Cretaceous Moosebar-lower Gates interval - outcrop equivalents of deep basin gas trap in western Canada. American Association of Petroleum Geologists Bulletin, 66, 138-157.

[10] Nichols, G. 2009. Sedimentology and Stratigraphy. $2^{\text {nd }}$ Ed. Oxford, Pp. 419.

[11] Clifton, H.E. 2006. A re-examination of facies models for clastic shorefaces. Facies Models Revisited. : In: Posamentier, H.W., Walker, R.G. (Eds.), Special Publication SEPM (Society for Sedimentary Geology), Tulsa, USA, 84, 293-337.

[12] Kidwells. 1991. Condense ddeposits in siliciclastic sequences: expected and observed features, Cycle sand events in stratigraphy, 682695.

[13] Di celma, C., Ragaini, L., Cantalamessa, G., Landini, W. 2005. Basin physiography and tectonic influence on sequence architecture and stacking pattern: Pleistocene succession of the Canoa Basin (central Ecuador), Geological Society of America Bulletin, 117 (9-10), 1226-1241.

[14] Swift, D.J.P., Oertel, G., Tillman, R., Thorne, J. 1991. Shelf sand and sandstone bodies; geometry, facies and sequence stratigraphy: Oxford, UK, International Association of Sedimentologists Special Publication, 14, 532.

[15] Clifton, H.E. 1976. Wave-formed sedimentary structures-A conceptual model, in Davis, R.A., Jr., and Ethington, R.L., eds., Beach and Nearshore Sedimentation: Society for Sedimentary Geology (SEPM) Special Publication, 24, 126-148.

[16] Fiah, N.M., Lambiase, J.J. 2014. Ichnology of shallow marine clastic facies in the Belait Formation, Brunei Darussalam. Bulletin of the Geological Society of Malaysia, 60, 55-63.

[17] Arnott, R.W.C. 1992. Ripple cross-stratification in swaley crossstratified sandstones of the Chungo Member, Mount Yamnuska, Alberta: Canadian Journal of Earth Sciences, v. 29, 1802-1805.

[18] Dott, R.H., Bourgeois, J. 1982. Hummocky cross stratification: significance of its variable bedding sequences. Geological Society of America Bulletin, 93, 663-680.

[19] Khan, A., Aslam, M., Rahman, E. 2017. Wave-dominated shoreline sediments in early cretaceous surajdeval formation, saurashtra basin, gujarat western india. International Journal of New Technology and Research, 3 (2), 74-78.

[20] Vakarelov, B.K., Ainsworth, R.B., MacEachern, J. 2012. Recognition of wave dominated, tide-influenced shoreline systems in the rock record: Variations from a microtidal shoreline model. Elsevier, 23-41.

[21] Walker, R.G., Plint, A.G. 1992. Wave- and storm-dominated shallow marine systems. In: Walker, R.G., James, N.P. (Eds.), Facies Models, Response to Sea Level Change. Geological Association of Canada, St. John's, NF, Canada, pp. 219-238.

[22] Howard, J.D., Frey, R.W. 1984. Characteristic trace fossils in nearshore to offshore sequences, Upper Cretaceous of east-central Utah. Canadian Journal of Earth Sciences (21), 200-219. 